\title{
Myocardial infarction in antiphospholipid antibody syndrome
}

\author{
Davide Lazzarini*, Luca Morolli, Jonathan Montomoli, Giorgio loli
}

Third Department of Medicine, Santarcangelo di Romagna, Azienda USL di Rimini, Rimini, Italy; *Corresponding Author: davide.lazzarini@auslrn.net

Received 1 December 2009; revised 13 May 2010; accepted 15 May 2010.

\begin{abstract}
A 52-year-old man was admitted to hospital with chest pain after physical activity. Emergency coronary angiography showed multiple thromboembolic occlusions in the anterior descending coronary artery and in the right coronary artery. Further testing revealed anticardiolipin and $\beta 2$-glicoprotein antibodies (the patient had been diagnosed for ulcerative colitis and polymyalgia rheumatica). Heparin and nitrate were administered intravenously in addition to oral aspirin and metoprolol. Soon after, the patient referred a withdrawal of chest oppression, and his general clinical condition rapidly stabilised. A follow-up examination was performed 9 months later the discharge: he had resumed most of his activities and sieric concentration of lupus anticoagulant antibodies and anticardiolipin antibodies, IgM isotype, were decreased.
\end{abstract}

Keywords: Antiphospholipid Antibody Syndrome; Myocardial Infarction; Anticardiolipin Antibodies; B2-Glicoprotein Antibodies

\section{INTRODUCTION}

Antiphospholipid antibody syndrome is a disorder of coagulation characterized by recurrent vascular thrombosis, pregnancy loss and thrombocytopenia associated with persistently elevated levels of antiphospholipid antibodies. Antiphospholipid antibodies are a heterogenous group of immunoglobulins IgG, IgM or, less frequently IgA.

Antiphospholipid antibody syndrome is present if there are at least one of the clinical criteria (vascular thrombosis, pregnancy morbidity) and one of the laboratory criteria (lupus anticoagulant, anticardiolipin antibody, anti $\beta 2$-glicoprotein antibodies) [1]. Antiphospholipid anti body syndrome falls into two main classifications: PRIMARY, if there are no other autoimmune disorder such as syste- mic lupus eythematosus (the cause of primary antiphospholipid syndrome in unknowm, but some factors are associated with developing antiphspholipid antibodies, such as infections, certain drugs or genetic predispositions); SECONDARY, if there are other autoimmune disorders [2], such as systemic lupus erythematosus.

\section{CASE REPORT}

A 52-year-old man was admitted to our hospital with a 20 -hour history of angina pectoris and dyspnoea. He referred chest pain following physical activity for several days.

Family medical history was insignificant.

The patient had been diagnosed for ulcerative colitis (1995) and polymyalgia rheumatica (2000). In 2001 the patient tested positive for lupus anticoagulant antibodies. Further testing revealed elevated titlers of anticardiolipin antibodies $(89 \mathrm{U} / \mathrm{ml} ; \mathrm{NV}=<28 \mathrm{U} / \mathrm{ml}) ; \beta 2$-glicoprotein antibodies $(100 \mathrm{MU} / \mathrm{ml} ; \mathrm{NV}=<17 \mathrm{MU} / \mathrm{ml})$ and rheumatoid factor $(190 \mathrm{U} / \mathrm{ml} ; \mathrm{NV}=<15 \mathrm{U} / \mathrm{ml})$. Both the anticardiolipin and the $\beta 2$-glicoprotein antibodies were IgM isotypes. No clinical symptoms of venous thrombosis were found. In 2002, the lupus anticoagulant antibodies were absent, and the patient was diagnosed for ischemic dilated (congestive) cardiomyopathy with occlusion of the distal portion of the anterior descending coronary artery. Prior to hospitalization the patient was taking prednisone $5 \mathrm{mg}$ diem, lysin acetylsalicylate 75 $\mathrm{mg}$ diem and mesalazin $4 \mathrm{~g}$ periodically.

On clinical examination, the patient had a normal body temperature, a blood pressure of $100 / 60 \mathrm{mmHg}$, a heart rate of 78 beats/min and a respiratory rate of 22 breath $/ \mathrm{min}$. Heart beats were regular without murmurs, bruits or gallops, while lung auscultation revealed fine and coarse crackles. He reported muscle aching and a bit of stiffness in the neck, shoulders and upper arms. The rest of his examination was normal.

The electrocardiogram showed a QS pattern without ST elevation in leads V1-V6, DII and aVF. An emergency 
echocardiogram demonstrated hypokinesis of the anterior, lateral and septal walls.

Emergency coronary angiography showed multiple thromboembolic occlusions in the distal circumflex and anterior descending coronary artery and in the marginal branch of the right coronary artery. Haemoglobin was 11 $\mathrm{g} / \mathrm{dl}(\mathrm{NV}=12 \mathrm{~g} / \mathrm{dl})$; white blood cell count was $13 \times$ $10^{3} / \mu \mathrm{l}\left(\mathrm{NV}=8-10 \times 10^{3} / \mu \mathrm{l}\right)$ and platelets were $317 \times$ $10^{3} / \mu \mathrm{l}\left(\mathrm{NV}=150-400 \times 10^{3} / \mu \mathrm{l}\right)$. Partial Thromboplastin Time was $27.3 \mathrm{sec}(\mathrm{NV}=25-39 \mathrm{sec})$ and the International Normalized Ratio was $1.3(\mathrm{NV}=0.8-1.2)$. Creati-nine Kinase $-\mathrm{MB}$ peaked at $140 \mathrm{U} / \mathrm{l}(\mathrm{NV}=5-$ $130 \mathrm{U} / 1)$.

Heparin and nitrate were administered intravenously in addition to oral aspirin and metoprolol. Soon after, the patient referred a withdrawal of chest oppression, and his general clinical condition rapidly stabilised. The patient was discharged from the hospital on the seventh day with only aspirin therapy at $325 \mathrm{mg} / \mathrm{die}$ [3].

A follow-up examination was performed 9 months later. The patient was well and had resumed most of his activities. The clinical examination was normal. The $\mathrm{C}$ reactive protein level was $6.76 \mathrm{mg} / \mathrm{l}$, and sieric concentration of lupus anticoagulant antibodies and anticardiolipin antibodies, IgM isotype, were $30.5 \mathrm{U} / \mathrm{ml}$.

\section{DISCUSSION}

We believe this case report to be of some interest because it underlines some unusual aspects of secondary antiphospholipid antibody syndrome such as the absence of venous thrombosis, multiple thromboembolic occlusions of coronary arteries without interest elsewhere [4,5], the temporary absence of the lupus anticoagulant antibodies and the absence of thrombocytopenia. Another interesting fact is the contemporary presence of antiphospholipid antibody syndrome and polymyalgia rheumatica, independent diseases rarely present in the same patient [6].

The diagnosis of definite antiphospholipid antibody syndrome requires the presence of at least one of the clinical criteria and at least one of the laboratory criteria.
However, no limits are placed on the interval between the clinical event and the positive laboratory findings [7]. In this patient the antiphospholipid antibody syndrome was diagnosed by the presence of one clinical (episodes of coronary thrombosis with angina) and two laboratory criteria (anticardiolipin IgM antibodies present in the blood on two occasions at least six weeks apart; lupus anticoagulant antibodies detected in the blood on two occasions at least six weeks apart).

This case-report underlines the presence of antiphospholipid antibody as a risk factor in ischemic cardiopathy.

\section{REFERENCES}

[1] Miyakis, S., Lockshin, M.D., et al. (2006) International consensus statement on an update of the classification criteria for definite antiphospholipid syndrome (APS). Journal of Thrombosis Haemostasis, 4(2), 295-306.

[2] Levine, J.S., Branch, D.W. and Rauch, J. (2002) The antiphospholipid syndrome. New England Journal of Medicine, 346(10), 752-763.

[3] Wahl, D.G., Bounameaux, H., de Moerloose, P., et al. (2000) Prophylactic antithrombotic therapy for patients with systemic lupus erythematosus with or without antiphospholipid antibodies: Do the benefits outweight the risks? A decision analysis. Archives of Internal Medicine, 160(13), 2042-2048.

[4] Ogimoto, A., Sekiya, M., Funada, J., et al. (2000) Antiphospholipid syndrome with acute myocardial infarction and portal vein occlusion. Journal of Japanese Circulation, 64(6), 468-470.

[5] Ikeda, Y., Yagi, S., Yamaguchi, H., et al. (2006) Intravascular ultrasound findings of diffuse coronary atherosclerotic change in systemic lupus erythematosus with secondary antiphospholipid syndrome. Circulation Journal, 70(8), 1082-1085.

[6] Ruffatti, A., Montecucco, C., Volante, D., et al. (2000) Antiphospholipid antibody syndrome and polymyalgia rheumatica/giant cell arteritis. Rheumatology, 39(5), 565567.

[7] Harris, E.N., Khamastha, M.A. and Hughes, G.R.D. (1993) Antiphospho-lipid antibody syndrome. In: McCarty, D.J. and Koopman, W.J., Eds., Arthritis and Allied Conditions, Lea and Febinger, Philadelphia, 1201-1212. 